
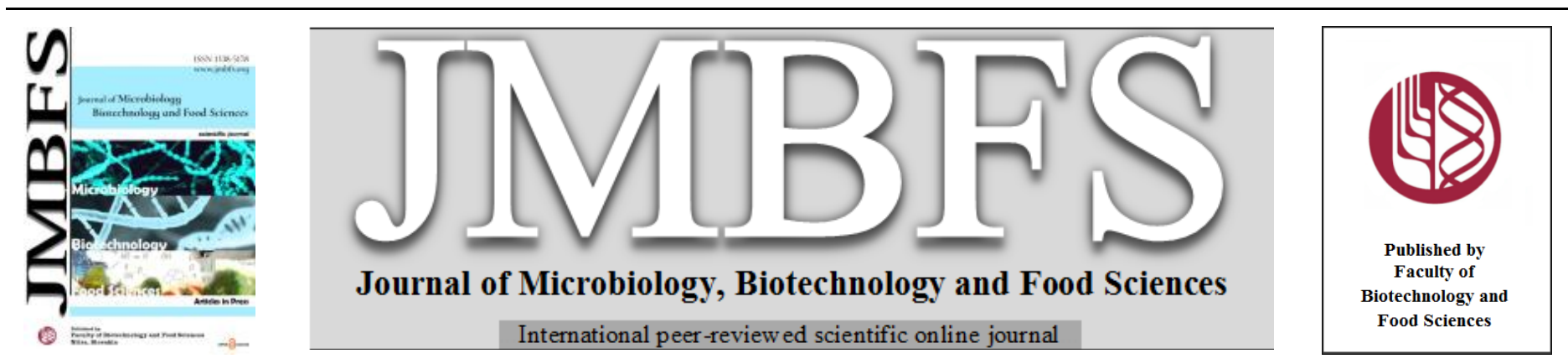

\title{
COMPARISON OF DNA STANDARDS FOR REAL-TIME PCR-BASED QUANTIFICATION OF LACTOBACILLUS ACIDOPHILUS IN DAIRY PRODUCTS
}

\author{
Monir-Sadat Shakeri * \\ Address(es): \\ Department of Food Biotechnology, Research Institute of Food Science and Technology (RIFST), Mashhad, Iran.
}

*Corresponding author: m.shakeri@ rifst.ac.ir

https://doi.org/10.55251/jmbfs.3738

\section{ARTICLE INFO}

Received 21.9. 2020

Revised 26. 9. 2021

Accepted 29. 9. 2021

Published 1. 2. 2022

\section{Regular article}

open $\partial_{\text {Access }}$

\begin{abstract}
Probiotic bacteria are an essential part of the healthy gut microbiota. Fermented foods as potential sources of health-promoting bacteria can regulate the intestinal microbial population. However, the exact quantification of these bacteria in such multiple-strain matrixes continues to remain elusive. In this study, we evaluated the reliability of genomic DNAs and cloned recombinant plasmids as standard controls for absolute real-time PCR assay. The associated standard curves were constructed and used for the quantification of Lactobacillus acidophilus probiotics. All stages from the design and construction of standards and related curves met the criteria for high-quality products. There were no significant differences between the two enumeration methods. However, plasmid-based standard curves resulted in a lower detection limit than the curves of genomic DNA standards. Our findings showed that the non-linearized recombinant plasmids had long-term stability at high concentrations during storage at $-20^{\circ} \mathrm{C}$, which strongly depended on the purification methods. We propose that the recombinant plasmid standards can supersede the traditional genomic DNA standards for accurate quantification of probiotic bacteria.
\end{abstract}

Keywords: Recombinant DNA; Plasmid standard; DNA calibrator; Standard curve; Bio-yoghurt

\section{INTRODUCTION}

Lactobacilli are common probiotics in food owning the specific beneficial health properties (Fijan et al. 2019). Lactobacillus acidophilus is one of the bestrecognized species of the genus lactobacillus. Based on morphological properties, these bacteria are gram-positive and non-spore-forming rods. They are found in different commercial fermented milks because of intestinal probiotic effects and modulation of the host microbiome (Widyastuti $\boldsymbol{e t}$ al. 2021). Identification of these bacteria is essential to discriminate them from phylogenetically similar strains with different properties. Therefore, reliable procedures are required for qualitative and quantitative detection of probiotic bacteria.

There are different PCR-based quantification techniques such as competitive PCR, real-time PCR, and digital PCR (Zentilin and Giacca 2007; Papic et al. 2017) (Fig. 1). Real-time PCR (qPCR) is the most precise method by which to measure genes. It is now a well-known method for identification, quantification, and microbial community analysis that covers a wide range of applications in medicine and food safety. In real-time PCR, DNA amplification is tracked through the monitoring of fluorescence. Although the basic principles of PCR are simple, there are some specific issues in qPCR to achieve reliable quantification (Kralik and Ricchi 2017). Problems such as primer dimers, amplification of non-specific products, and heterogeneous efficiency of amplification may occur that users must have previously thought about them.

Absolute real-time PCR quantification using the standard curve method is the most common technique used in environmental and food microbiology (Brankatschk et al. 2012). In fact, to address the issues associated with non-uniform PCR efficiencies in different samples, the standard curve method is uncomplicated and reliable (Larionov et al. 2005). A standard curve can be created by amplification of serial dilutions of known concentration of standard template followed by linear regression of the log of DNA concentrations of the standard templates versus threshold cycle $(\mathrm{Ct})$. In this method, it is presumed that the efficiency of both sample and standard are the same (Mackay 2004; Brankatschk et al. 2012). However, in practice they may not be similar, which affects the quantification accuracy. Hence the reliability and validity of the standard curve are a matter of interest. It depends on the design and production of standard control, measurement of the exact concentration, and long storage stability (Pfaffl 2004). To overcome the fluctuations of efficiency, it is crucial that both the standard dilutions and the unknown samples amplify in the same protocol and with the same amplification properties (Taylor $\boldsymbol{e t}$ al. 2019). Moreover, it is undoubtedly associated with the choice and quality of standard controls. They should have excellent properties such as purity, indivisibility, and stability. Purified PCR product, plasmid DNA construct, genomic DNA, cDNA, or synthetic oligonucleotide spanning the PCR amplicon can be used as a DNA standard control or calibrator. Between them, cloned recombinant plasmid DNA and genomic DNA generate reproducible standard curves due to high stability (Pfaffl 2004; Boulter et al. 2016). However, MIQE guidelines have introduced the best practices to facilitate standardization of qPCR assay. Some issues related to finding suitable controls to generate a standard curve for each gene of interest are still remained (Boulter $\boldsymbol{e t}$ al. 2016).

In the current study, we designed a plasmid DNA construct containing the target gene of L. acidophilus bacteria. The constructed plasmid was compared with genomic DNA as standards for absolute real-time PCR assay with the aim of accurate enumeration of these probiotics.

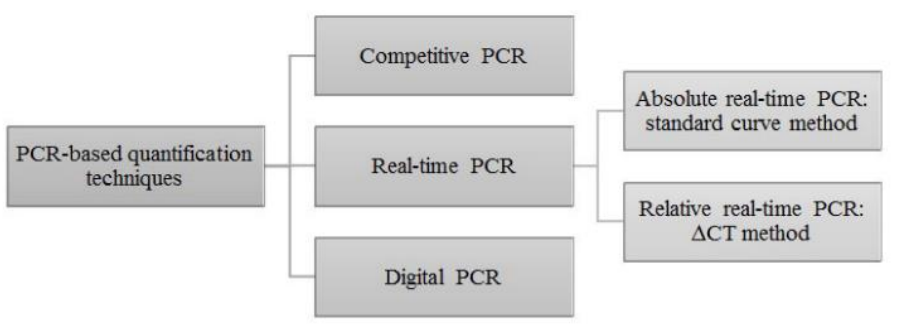

Figure 1 Different types of PCR-based quantification methods

\section{MATERIALS AND METHODS}

\section{Bacterial Strain and Food Samples}

L. acidophilus bacteria were from American Type Culture Collection (ATCC 4356) and activated in de Man Rogosa Sharpe (MRS) broth (Merck-Darmstadt, Germany) at $37^{\circ} \mathrm{C}$. Commercial bio-yoghurts with yoghurt culture organisms, $L$. acidophilus and bifidobacteria, were obtained in IRAN. Surface plating on MRS agar was used for the classical enumeration of the bacteria. The plates were incubated at $37^{\circ} \mathrm{C}$ for $72 \mathrm{~h}$ under anaerobic conditions. 


\section{DNA Extraction}

Genomic DNAs of bacterial pellets from overnight liquid cultures and bio-yoghurt samples were extracted with an AccuPrepTM Genomic DNA Extraction Ki (Bioneer, Korea). The protocol slightly modified for increased extraction efficiency as previous work by Shakeri et al. (Shakeri et al. 2018). Briefly, bacteria were harvested from $1 \mathrm{~mL}$ of overnight culture based on McFarland turbidity standards (approximately $10^{8} \mathrm{cfu} / \mathrm{mL}$ ) by centrifugation. The pellet was mixed with $500 \mu \mathrm{L}$ of TE (10 mM Tris- $\mathrm{HCl} \mathrm{pH} 8.0 ; 1 \mathrm{mM}$ EDTA) buffer and 15 $\mathrm{mg} / \mathrm{mL}$ lysozyme followed by incubation at $37^{\circ} \mathrm{C}$ for $1 \mathrm{~h}$. All other purification steps were done according to the protocol described in the kit. The purity of DNA was checked on a nanodrop spectrophotometer (Nanodrop Technologies, DE, USA) by absorbance detection at 260,280 , and $230 \mathrm{~nm}$.

\section{Construction of the Plasmid DNA as Standard}

The plasmid encoding part of the L. acidophilus 16S rRNA gene was constructed through the amplification of a 227- bp fragment within the conserved region of the $16 \mathrm{~S}$ rRNA gene using the specific primer pairs including Acidfor (5' AGCGAGCTGAACCAACAGAT-3') and Acidrev (5' AGGCCGTTACCCTACCAACT-3'). This primer set was previously designed by Tabasco et al. (Tabasco et al. 2007), and has been used before by Shakeri et al. (Shakeri et al. 2018). The primer sequences and PCR conditions with the genomic DNA of the bacteria as the template were similar to the previous study published by these authors.

The amplified fragments were visualized using agarose gel electrophoresis, and the band size verified. They were purified using a DNA extraction kit K0513 (EN0525; Fermentas, Vilnius, Lithuania), according to the manufacturer's protocol. The purified DNA segment was TA cloned into Escherichia coli DH5 alpha using TA Cloning Kit K1214 (EN0525; Fermentas). The plasmid DNA was then extracted using the High Pure Plasmid Isolation Kit (Roche, Germany) based on the kit manual. Freshly extracted plasmids were linearized with the restriction endonuclease that cuts the BamHI site near the inserted PCR target (Fig. 2) and purified. The concentration of linearized plasmids quantified using the UV absorbance $\left(\mathrm{OD}_{260}\right)$ method. PCR was performed on the purified plasmids using Acidfor and Acidrev primers. Moreover, the presence of the target gene was confirmed via the digestion of BamHI and EcoRI sites. All the enzyme assays were carried with $2 \mathrm{U}$ of each enzyme at $37^{\circ} \mathrm{C}$ for $2 \mathrm{~h}$. Based on the molecular weigh of the designed plasmid DNA (plasmid plus insert) and its concentration, the number of copies per $\mu \mathrm{L}$ was calculated using the formula described by Kibbe, (Kibbe, 2007).

We also extracted the plasmid DNA by the basic manual alkaline lysis method for stability analysis during storage (Sambrook and Russel, 2001). The stability of the standards (plasmid and genomic DNAs) was checked by measuring the tota DNA concentrations after three years of storage at $-20{ }^{\circ} \mathrm{C}$. The mean of the percentage of variance from triplicates was calculated using Excel (Microsoft, Unterschleissheim, Germany).

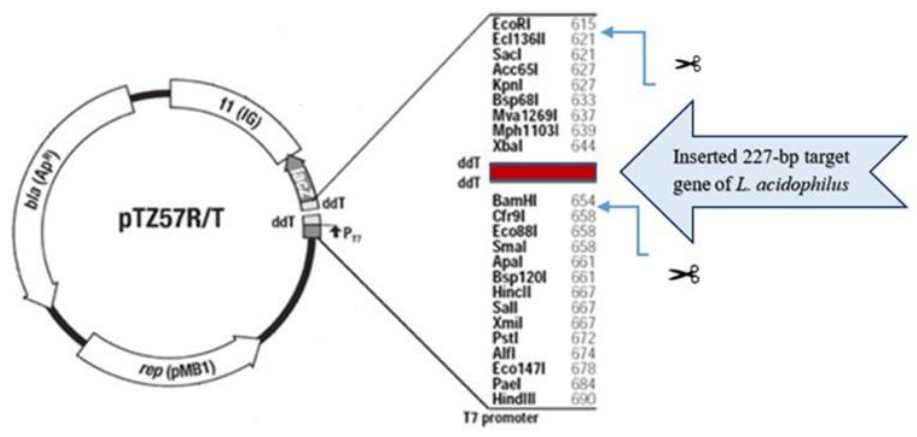

Figure 2 Physical genetic map of recombinant pTZ57R/T plasmid carrying the $16 \mathrm{~S}$ rRNA-based target gene of $L$. acidophilus

\section{Construction of Standard Curves}

To prepare the standard curves for molecular quantification of L. acidophilus bacteria, two standard controls, including genomic DNA and cloned recombinant plasmid DNA containing the target sequence, were used.

To construct the standard curve with genomic DNA, bacterial genomic DNA from an overnight culture of L. acidophilus bacteria with a cell concentration of $6 \times 10^{8}$ $\mathrm{cfu} / \mathrm{mL}$ was serially diluted in nuclease-free water (Sigma). In this way, we prepared a set of standard dilutions of genomic DNA that is equivalent with the known concentration of bacterial cells ranging from about $6 \times 10^{2}$ to $6 \times 10$ $\mathrm{cfu} / \mathrm{mL}$. The real-time PCR assay was performed with five serial dilutions of standard DNA samples as a template. The correlation between $\mathrm{Ct}$ values and log concentration of L. acidophilus bacteria (cfu/mL) in standard samples was used for generating the standard curve by linear regression analysis in Microsoft Excel.
To generate the plasmid DNA-based standard curve, the stock plasmid solution with a concentration of $1.49 \times 10^{10}$ copy $/ \mu \mathrm{L}$ was serially diluted in DNA grade water. Subsequently, these serial 10 -fold dilutions of the standard plasmid $(2.98 \times$ $10^{1}$ to $2.98 \times 10^{8}$ DNA copies per reaction in $2 \mu \mathrm{L}$ ) were used to $\mathrm{qPCR}$ amplification. The standard curve was constructed by plotting the $\mathrm{Ct}$ values against the log copy numbers of the designed plasmid in standard samples using the linear regression, as described above.

To obtain the numbers of cfu, extracted DNA from a bacterial suspension of $6 \times$ $10^{5} \mathrm{cfu} / \mathrm{mL}$ was subjected to the qPCR assay using this standard plasmid curve and the copy number of plasmids equivalent to the number of bacterial cells was calculated. Mean Ct values from duplicates (two repeats) were calculated and used for generating an average standard curve from each standard construct.

\section{Real-time PCR Quantification and Data Analysis}

Real-time PCR was carried on CFX96 Touch ${ }^{\mathrm{TM}}$ Bio-Rad Cycler (Bio-Rad Hercules, CA, USA). The final reaction volume was $25 \mu \mathrm{L}$, including Maxima SYBR Green qPCR Master Mix (Fermentas, Vilnius, Lithuania) and 5 pmol of both Acidfor and Acidrev primers, $1 \mu \mathrm{L}$ of DNA template, and DNase free water. The real-time PCR cycling parameters were the following: $95^{\circ} \mathrm{C}$ for $10 \mathrm{~min}$ followed by 40 cycles of $95^{\circ} \mathrm{C}$ for $15 \mathrm{~s}, 60^{\circ} \mathrm{C}$ for $20 \mathrm{~s}$ and $72^{\circ} \mathrm{C}$ for $30 \mathrm{~s}$. Reactions containing ddH2O as no-template controls (NTC) were included in each run. At the end of the amplification, melting curve analysis was run to confirm the presence of the single desired product in each reaction. All reactions were performed in triplicate. According to the constructed standard curves, the number of $L$. acidophilus bacteria in pure cultures (containing a known concentration of $L$. acidophilus bacteria) and commercial bio-yoghurts was calculated and compared Statistical differences in the quantification observed between two standard curve methods were examined by paired t-test using SigmaStat (SigmaStat Statistical Software, Version 4.0, Jandel Corporation, San Rafael, CA, USA). $95 \%$ confidence interval $(\mathrm{P} \leq 0.05)$ was considered in the test.

\section{RESULTS AND DISCUSSION}

\section{Constructed Plasmid DNA}

The designed plasmid, including the target region of $L$. acidophilus $16 \mathrm{~S}$ rRNA gene, was successfully generated, and the structural integrity of the plasmid sample was confirmed (Fig. 3A). The dominant conformation of the isolated plasmid DNA was a supercoiled form. However, linear and nicked-circular plasmid forms were also observed. Non-linearized plasmids result in different efficiencies during the PCR reaction (Dhanasekaran et al. 2010). So the extracted plasmid DNA was linearized and then used as templates for the standard curve. Moreover, enzymatic digestion analysis and PCR amplification with the specific target primers verified the accuracy of the plasmid carrying the 227-bp target gene of L. acidophilus (Fig. 3B)
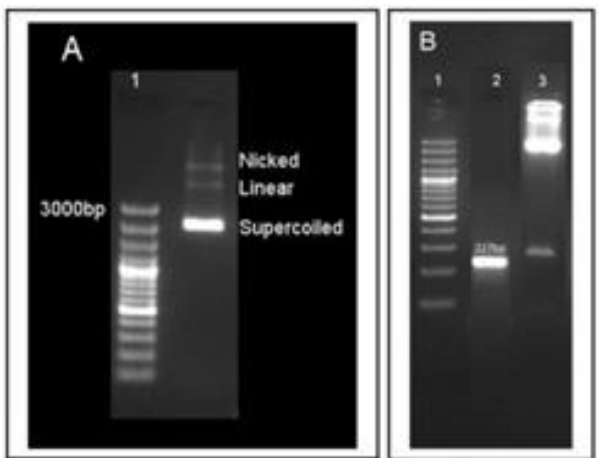

Figure 3 Properties of constructed plasmid DNA: A, Gel electrophoresis of the isolated plasmid DNA (nicked, linear and supercoiled forms). B, verification of inserted target through restriction enzyme digestion and colony PCR. Lane 1: 100 bp DNA ladder (Thermo Scientific, USA). Lane 2: PCR product (227 bp) on the generated plasmid DNA. Lane 3: a band of $266 \mathrm{bp}$ produced from double digestion of BamHI/EcoRI sites on the constructed plasmid

\section{Generated Standard Curves}

As shown in Fig. 4A, the standard curve generated from genomic DNA as a calibrator had a linear range between $6 \times 10^{2}$ and $6 \times 10^{7} \mathrm{cfu} / \mathrm{mL}$ with slopes of 3.424. The amplification efficiency of the genomic DNA used for developing the standard curve was $95.9 \%$, with a regression coefficient $\left(\mathrm{R}^{2}\right)$ value of 0.996

The standard curve of 10 -fold dilutions of the recombinant plasmid DNA as a calibrator is shown in Fig. 4B. The amplification efficiency and $\mathrm{R}^{2}$ were $99.8 \%$ and 0.99 , respectively. The linear dynamic range was considered between $2.98 \times$ $10^{1}$ and $2.98 \times 10^{8}$ DNA copies per reaction with slopes of -3.326 , which indicated that the amplification was well performed. For both standard curves, the therma dissociation curves were checked at the end of each PCR, and always had a unique 
melting point of $82.5^{\circ} \mathrm{C}$, without any additional peak, indicating single PCR products. Amplified fragments of the expected size were also verified by gel electrophoresis (Fig. 5).

In general, a suitable standard curve is characterized by factors including slope, PCR efficiency, and correlation coefficient. Ideally, the slope should be -3.33 , which corresponds to $100 \%$ efficiency or two-fold (precisely, 2.0092) amplification at each cycle. Also, correlation coefficient should be $>0.99$ for gene quantitation analysis (Pfaffl 2004; Dorak 2006). In practice, an optimal standard curve should have efficiency as close to $100 \%$ as possible (90-110\%), the slope between -3.1 to -3.6 with low variation and a high correlation coefficient However, slope values between -3.2 and -3.4 indicate that the reaction is well optimized (Dorak 2006; Matijasic et al. 2010; Taylor et al. 2019). According to our results, appropriate efficiency, accuracy, and sensitivity were observed for both standard curve methods. However, the linear range of the plasmid-based standard curve was greater with a lower limit of detection (LOD). According to the lowest number point on the standard curves, the LOD for genomic and plasmid DNAs were 600 and $10 \mathrm{cfu} / \mathrm{mL}$, respectively.

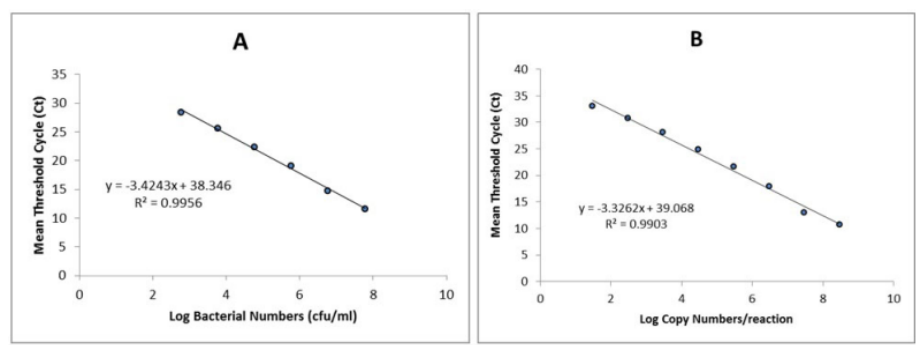

Figure 4 Standard curves for qPCR enumeration of L. acidophilus bacteria: A Standard curve obtained from real-time PCR of 10-fold dilution series of extracted genomic DNA of L. acidophilus bacteria. B, Standard curve obtained from real- time PCR of serial dilutions of the designed plasmid DNA in which the target 16S rRNA gene of $L$. acidophilus bacteria is inserted
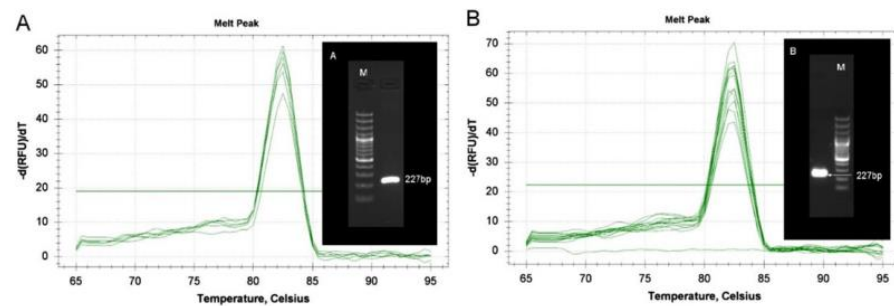

Figure 5 Melting curve analysis and gel electrophoresis visualization for the realtime PCR products with the used primer set and standard DNAs: A, genomic $L$. acidophilus DNA as a template and $\mathrm{B}$, the constructed plasmid DNA as template. M: 100 bp DNA ladder (Thermo Scientific, USA)

\section{Comparative Analysis of Two Standard Curve Methods}

For comparison between two generated standard curves, DNA extracted from three suspensions of $L$. acidophilus bacteria was quantified using two methods. The results showed that there were no significant differences between the counts of bacterial cells (Table 1). Both assays represented more than $97 \%$ recovery with low variability in repeatability. Similarly, two standard curve methods did not have significant differences on the enumeration of these bacteria in bio-yoghurt samples (Table 2). Most of the previous studies on molecular quantification of probiotic bacteria have used genomic DNAs or PCR products as standards (Furet $\boldsymbol{e t}$ al. 2004; Ongol et al. 2009; Sattler et al. 2014). However, plasmid DNAs have presented highly efficient detections of food-borne pathogens, which is similar to our results (Liu et al. 2019). Moreover, the plasmids were suitable calibrators for the quantification of genetically modified content of the food (Burns et al. 2006).

Table $1 \mathrm{gPCR}$ quantification of L. acidophilus bacteria in pure cultures based on genomic and recombinant plasmid DNA standard curves

\begin{tabular}{|c|c|c|c|c|c|}
\hline \multirow{3}{*}{$\begin{array}{l}\text { Standard curve } \\
\text { methods }\end{array}$} & \multirow{3}{*}{$\begin{array}{l}\text { Expected numbers } \\
\quad(\log \mathrm{cfu} / \mathrm{mL})\end{array}$} & \multirow{3}{*}{$\begin{array}{l}\text { Observed numbers } \\
\quad(\log \mathrm{cfu} / \mathrm{mL})^{\mathrm{a}}\end{array}$} & \multicolumn{2}{|l|}{ Reliability } & \multirow[t]{3}{*}{ Paired t- test $(\alpha=0.05)$} \\
\hline & & & Repeatability & Variability & \\
\hline & & & $\operatorname{Recovery}^{\mathbf{b}}(\%)$ & $\begin{array}{c}\text { RSD }^{\mathbf{c}} \\
(\%)\end{array}$ & \\
\hline GDM & 7.176 & $7.077 \pm 0.122$ & 98.561 & 1.727 & $\mathrm{P}=0.695(\mathrm{~ns})^{\mathrm{d}}$ \\
\hline PDM & & $7.100 \pm 0.126$ & 98.886 & 1.773 & \\
\hline GDM & 5.176 & $5.127 \pm 0.117$ & 98.970 & 2.274 & $\mathrm{P}=0.691(\mathrm{~ns})$ \\
\hline PDM & & $5.147 \pm 0.131$ & 99.357 & 2.550 & \\
\hline GDM & 3.176 & $3.107 \pm 0.116$ & 97.694 & 3.739 & $\mathrm{P}=0.971(\mathrm{~ns})$ \\
\hline PDM & & $3.113 \pm 0.115$ & 97.904 & 3.704 & \\
\hline
\end{tabular}

GDM; genomic DNA-based method, PDM; Plasmid DNA-based method, ns; non-significant.

${ }^{\mathrm{a}}$ Mean $\pm \mathrm{SD}(\mathrm{n}=3)$.

${ }^{\mathrm{b}}$ Recovery: observed number/expected number $\times 100 \%$.

${ }^{\mathrm{c}} \mathrm{RSD}$ : relative standard deviation $=\mathrm{SD} /$ Mean $\times 100 \%$.

${ }^{\mathrm{d}}$ Two-tailed P-value.

Table 2 Enumeration of L. acidophilus bacteria in bio-yoghurt samples based on genomic and recombinant plasmid DNA standard curves.

\begin{tabular}{lcc}
\hline Standard curve methods & $\begin{array}{c}\text { Number of } \\
\text { bacteria }(\mathbf{l o g} \\
\mathbf{c f u} / \mathbf{m L})^{\mathbf{a}}\end{array}$ & $\begin{array}{c}\text { Paired t- test } \\
(\boldsymbol{\alpha}=\mathbf{0 . 0 5})\end{array}$ \\
\hline Genomic DNA-based method & $7.033 \pm 0.051$ & $\begin{array}{c}\text { non-significant } \\
\mathrm{p}=0.560\end{array}$ \\
Plasmid DNA-based method & $7.006 \pm 0.032$ & \\
\hline
\end{tabular}

${ }^{\mathrm{a}} \mathrm{Mean} \pm \mathrm{SD}(\mathrm{n}=3)$.

As shown in Fig. 6, the percentage of the variance of DNA concentration for different types of standards was also evaluated after three years of storage at -20 ${ }^{\circ} \mathrm{C}$. It was clear that the non-linearized recombinant plasmid DNA extracted by the used kit (non-linearized) had a variance of $<2 \%$, which is acceptable. However, the manual extracted plasmid DNA and genomic DNA showed a variation of $>10 \%$, indicating that the nature of the standard and isolation method could change the standard concentration during the storage time. Moreover, diluted standards were degraded completely (data was not shown). Similarly, Dhanasekaran et al (Dhanasekaran et al. 2010) demonstrated that PCR products cloned into nonlinearized plasmids were more stable than linearized plasmids containing the PCR products during 14 days of storage at $-20^{\circ} \mathrm{C}$. In spite of the PCR suppression effect of the supercoiled conformation of plasmids (Lin et al. 2011), our findings showed that this form of plasmids could maintain high stability. In similar, long-term stability $\left(3\right.$ years for $-20^{\circ} \mathrm{C}$ ) of the plasmids containing information DNAs have been previously demonstrated by Nguyen $e t$ al. (Nguyen et al. 2018). Changes in standard concentrations and copy numbers due to the degradation of the DNA targets cause the main variation in PCR efficiency of standards without altering the correlation coefficient. Hence, all of the mentioned factors, including PCR efficiency, concentration, and copy number variations as well as $\mathrm{R}^{2}$, are equally significant for accurate enumeration of probiotic bacteria.

According to these results, the use of the plasmid could be more precise because of its ease of maintenance and stability under long storage time, which can be lead to a more accurate enumeration of probiotic bacteria between various laboratories. Table 3 represents the technical and performance properties of these two standards. Because plasmid DNA is more stable and requires fewer replicates, the plasmidbased standard curve method has a higher throughput than genomic-based assay. The technique is also easy with universal applicability and reliable estimation of the copy number of the standards. The determination of plasmid DNAs is based on the molecular weight of the nucleotides, which is more precise than genomic DNAs. In general, the determination of the concentration and length of the shorter templates is more accurate (Pfaffl 2004). Finally, it is possible to construct a cloned recombinant plasmid containing several target genes of bacteria, which leads to the amplification of more target genes in a single reaction in qPCR assay. In this way, more bacteria can be detected simultaneously (Liu $\boldsymbol{e t}$ al. 2019). However, the production of standard material is an expensive and time-consuming process. 


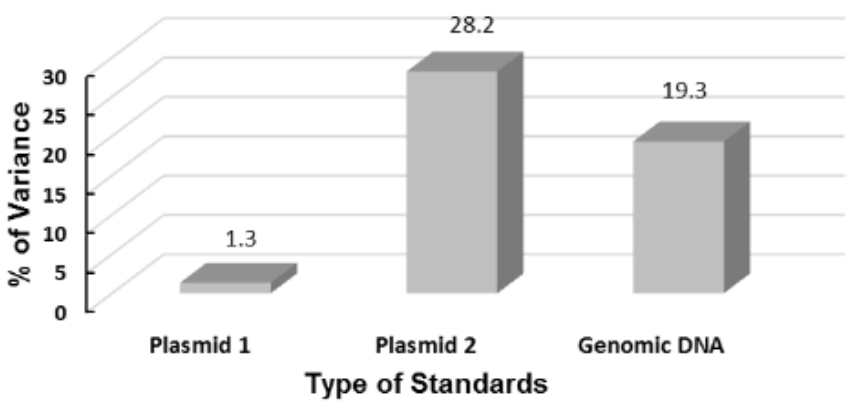

Figure 6 The Average percentage of the variance of DNA concentration for different standards $(\mathrm{n}=3)$. Plasmid 1: non-linearized recombinant plasmid DNA extracted by the commercial kit, Plasmid 2: non-linearized recombinant plasmid DNA obtained by the basic manual alkaline lysis method, and Genomic DNA extracted by the commercial kit

Table 3 Comparison of cloned recombinant plasmid DNA to genomic DNA as a calibrator in qPCR assay.

\begin{tabular}{lcc}
\hline Properties & $\begin{array}{c}\text { Plasmid } \\
\text { DNA }\end{array}$ & $\begin{array}{c}\text { Genomic } \\
\text { DNA }\end{array}$ \\
\hline Relative quantification & $\checkmark$ & $\checkmark$ \\
Absolute quantification & $\checkmark$ & $\checkmark$ \\
High accuracy & $\checkmark$ & $\checkmark$ \\
No specialized equipment & $\checkmark$ & \\
High throughput & $\checkmark$ & \\
Low replicates & $\checkmark$ & \\
No special preparation & & \\
Applicable for certified reference materials & $\checkmark$ & \\
High stability & $\checkmark$ & \\
High precision in copy number estimation & $\checkmark$ & \\
Multiple and simultaneous quantifications & $\checkmark$ & \\
of bacteria & &
\end{tabular}

\section{CONCLUSION}

Performance characteristics related to plasmid and genomic calibrators were investigated to find the best practice guide. The results demonstrated that plasmid standard outperformed genomic DNA in the quantification of L. acidophilu bacteria. When the related standard curve was generated, the limit of detection was $10 \mathrm{cfu} / \mathrm{mL}$, which was remarkably lower than the genomic DNA standard. The plasmid standard was very stable after three years of storage at $-20^{\circ} \mathrm{C}$. It was the first report on the long-term stability of the plasmid standards for real-time PCR quantification of probiotic bacteria. Conclusively, we tend to suggest using the plasmid-based standard curve method as a reliable and efficient alternative for quantification of probiotic bacteria in absolute real-time PCR. It can create a reproducible quantification which helps the standardization of qPCR assay. It should be added that standard curve materials should be routinely assessed for quality and stability.

Acknowledgements: The authors thank the personnel of the genomics laboratories of the Ferdowsi University of Mashhad.

\section{Compliance with Ethical Standards}

Conflict of Interest: The authors declare that they have no conflict of interest.

Ethical Approval: This article does not contain any studies with human participants or animals.

Informed Consent: This article does not contain any individual participants.

\section{REFERENCES}

Boulter N, Suarez FG, Schibeci S, Sunderland T, Tolhurst O, Hunter T, Hodge G Handelsman D, Simanainen U, Hendriks E, Duggan K (2016) A simple, accurate and universal method for quantification of PCR. BMC Biotechnology 16, 27. https://doi.org/ 10.1186/s12896-016-0256-y

Brankatschk R, Bodenhausen N, Zeyer J, Burgmann H (2012) Simple absolute quantification method correcting for quantitative PCR efficiency variations for microbial community samples. Applied and Environmental Microbiology, 78(12), 4481-4489. https://doi.org/10.1128/AEM.07878-11

Burns M, Corbisier P, Wiseman G, Valdivia H, McDonald P, Bowler P, Ohara K, Schimmel H, Charels D, Damant A, Harris N (2006) Comparison of plasmid and genomic DNA calibrants for the quantification of genetically modified ingredients. European Food Research and Technology 224, 249-258 https://doi.org/10.1007/s00217-006-0376-z

Dhanasekaran S, Mark Doherty T, Kenneth J, TB Trials Study Group (2010) Comparison of different standards for real-time PCR-based absolute quantification. Journal of Immunological Methods, 354, 34-39. https://doi.org/10.1016/i.jim.2010.01.004

Dorak MT (2006) Real-time PCR. New York: Taylor and Francis Group.

Fijan S, Frauwallner A, Varga L, Langerholc T, Rogelj I, Lorber M, Lewis P, Povalej Brzan P (2019) Health professionals' knowledge of probiotics: an international survey. International Journal of Environmental Research and Public Health, 16, 3128. https://doi.org/10.3390/ijerph16173128

Furet J, Quenee P, Tailliez P (2004) Molecular quantification of lactic acid bacteria in fermented milk products using real-time quantitative PCR. International $\begin{array}{llll}\text { Journal of Food } & \text { Microbiology, 97, 197-207. }\end{array}$ https://doi.org/10.1016/j.ijfoodmicro.2004.04.020

Kibbe WA (2007) OligoCalc: an online oligonucleotide properties calculator. Nucleic Acids Research, 35, Web Server issue W43-W46. https://doi.org/10.1093/nar/gkm234

Kralik P, Ricchi M (2017) A basic guide to real-time PCR in microbial diagnostics: definitions, parameters, and everything. Frontiers in Microbiology, 8, 108 https://doi.org/10.3389/fmicb.2017.00108

Larionov A, Krause A, Miller W (2005) A standard curve based method for relative real time PCR data processing. BMC Bioinformatics, 6,62 https://doi.org/10.1186/1471-2105-6-62

Lin C, Chen Y, Pan T (2011). Quantification bias caused by plasmid DNA conformation in quantitative real-time PCR assay. PLoS ONE, 6(12), e29101. https://doi.org/10.1371/journal.pone.0029101

Liu Y, Cao Y, Wang T, Dong Q, Li J, Niu C (2019). Detection of 12 common food-borne bacterial pathogens by TaqMan real-time PCR using a single set of reaction conditions. Frontiers in Microbiology, 10, 222 https://doi.org/10.3389/fmicb.2019.00222

Mackay IM (2004) Real-time PCR in the microbiology laboratory. Clinical Microbiology and Infection, 10, 190-212. https://doi.org/10.1111/j.1198 743X.2004.00722.x

Matijasic BB, Obermajer T, Rogelj I (2010) Quantification of Lactobacillus gasseri, Enterococcus faecium and Bifidobacterium infantis in a probiotic OTC drug by real-time PCR. Food Control, 21, 419-425. https://doi.org/10.1016/j.foodcont.2009.07.001

Nguyen HH, Park J, Park SJ, Lee CS, Hwang S, Shin YB, Ha TH, Kim M (2018). Long-term stability and integrity of plasmid-based DNA data storage. Polymers, 10, 28. https://doi.org/10.3390/polym10010028

Ongol MP, Tanaka M, Sone T, Asano K (2009). A real-time PCR method targeting a gene sequence encoding $16 \mathrm{~S}$ rRNA processing protein, rimM, for detection and enumeration of Streptococcus thermophilus in dairy products. Food Research International, 42, 893-898. https://doi.org/10.1016/j.foodres.2009.04.010

Papic B, Pate M, Henigman U, Zajc U, Gruntar I, Biasizzo M, Ocepek M, Kusar D (2017) New approaches on quantification of Campylobacter jejuni in poultry samples: the use of digital PCR and Real-time PCR against the ISO standard plate count method. Frontiers in Microbiology 8, 331 . https://doi.org/10.3389/fmicb.2017.00331

Pfaffl MW (2004) Quantification strategies in real-time PCR. In: Bustin SA (ed) A-Z of quantitative PCR. La Jolla, CA: International University Line (IUL).

Sambrook J, Russel D (2001) Molecular Cloning: A Laboratory Manual. New York: Cold Spring Harbor Laboratory Press.

Sattler VA, Mohnl M, Klose V (2014) Development of a strain-specific real-time PCR assay for enumeration of a probiotic Lactobacillus reuteri in chicken feed and intestine. PLoS ONE, 9(2), e90208. https://doi.org/10.1371/journal.pone.0090208 Shakeri M, Shahidi F, Mortazavi A, Bahrami AR, Nassiri MR (2018) Combination of competitive PCR and cultivation methods for differential enumeration of viable Lactobacillus acidophilus in bio-yoghurts. International Journal of Dairy Technology 70, 1-6. https://doi.org/10.1111/1471-0307.12536

Tabasco R, Paarup T, Janer C, Pelaez C, Requena T (2007) Selective enumeration and identification of mixed cultures of Streptococcus thermophilus, Lactobacillus delbrueckii subsp. bulgaricus, L. acidophilus, L. paracasei subsp. paracasei and Bifidobacterium lactis in fermented milk. International Dairy Journal 17, 1107 1114. https://doi.org/10.1016/j.idairyj.2007.01.010

Taylor SC, Nadeau K, Abbasi M, Lachance C, Nguyen M, Fenrich J (2019) The ultimate qPCR experiment: producing publication quality, reproducible data the first time. Trends in Biotechnology ,37(7), 761-774. https://doi.org/10.1016/j.tibtech.2018.12.002

Widyastuti Y, Febrisiantosa A, Tidona F (2021) Health-promoting properties of lactobacilli in fermented dairy products. Frontiers in Microbiology, 12: 673890 https://doi.org/10.3389/fmicb.2021.673890

Zentilin L, Giacca M (2007) Competitive PCR for precise nucleic acid quantification. Nature Protocol, 2(9), 2092-2104. https://doi.org/10.1038/nprot.2007.299 